\title{
PROPORTION OF CORNEAL BLINDNESS IN BLIND PATIENTS ATTENDING FOR BLIND CERTIFICATES IN REGIONAL EYE HOSPITAL, KURNOOL
}

\author{
Tatireddy Narasi Reddy 1 , K. Anjaneyulu², S. Vishnupriya ${ }^{3}$, C. Vijay Kanth ${ }^{4}$, K. Nagarani ${ }^{5}$
}

${ }^{1}$ Associate Professor, Department of Ophthalmology, Kurnool Medical College, Kurnool, Andhra Pradesh. ${ }_{2}^{2}$ Assistant Professor, Department of Ophthalmology, Kurnool Medical College, Kurnool, Andhra Pradesh. ${ }^{3}$ Postgraduate Student, Department of Ophthalmology, Kurnool Medical College, Kurnool, Andhra Pradesh. ${ }_{4}^{4}$ Postgraduate Student, Department of Ophthalmology, Kurnool Medical College, Kurnool, Andhra Pradesh. 5Postgraduate Student, Department of Ophthalmology, Kurnool Medical College, Kurnool, Andhra Pradesh.

\section{ABSTRACT}

\section{BACKGROUND}

The aim is to study the proportion of corneal blindness in blind patients attending for blindness certificates in Regional Eye Hospital, Kurnool.

\section{MATERIALS AND METHODS}

A total of 150 blind patients of all age groups attending Regional Eye Hospital, Kurnool for blindness certificates during the period of June 2015 to June 2016 were included and examined which include visual acuity testing using logMAR (logarithm of minimum angle of resolution), refraction, slit-lamp biomicroscopy, intraocular pressure measurement using Goldmann Applanation Tonometer and dilated fundus examination. Patients with the involvement of cornea were included in the study and those with other than corneal causes were excluded.

\section{RESULTS}

Out of 150 blind patients, corneal blindness with involvement of at least one eye was noted in 20 patients (13.3\%) out of which 13 (65\%) were male and $9(35 \%)$ were female.

\section{CONCLUSION}

In our study, corneal causes are the major cause of blindness in patients which constituted $13.3 \%$ of which ocular trauma (45\%) is the major cause of corneal blindness.

\section{KEYWORDS}

Corneal Blindness, Proportion, Biomicroscopy, Fundus Examination.

HOW TO CITE THIS ARTICLE: Reddy TN, Anjaneyulu K, Vishnupriya S, et al. Proportion of corneal blindness in blind patients attending for blind certificates in Regional Eye Hospital, Kurnool. J. Evolution Med. Dent. Sci. 2017;6(30):2407-2409, DOI: $10.14260 /$ Jemds/2017/519

\section{BACKGROUND}

In the developing countries, according to World Health Organization, blindness causes are cataract, glaucoma and followed by corneal diseases.(1) Blindness is a major health problem in developing countries.(2) Approximately, 6.8 million people have less than $6 / 60$ due to corneal diseases in India. ${ }^{(3,4)}$ According to the National Programme for Control of Blindness (NPCB) estimates, there are currently 120,000 corneal blind persons in the country. Every year 25,000 to 30,000 new corneal blind cases are added in India. Ninety percent of the corneal blindness is due to ocular trauma and corneal ulceration in the developing countries. (5)

\section{MATERIALS AND METHODS}

The present study was conducted on 150 blind people who attended Regional Eye Hospital, Kurnool for blindness certificates during the period of June 2015 to June 2016.

Financial or Other, Competing Interest: None.

Submission 24-02-2017, Peer Review 30-03-2017,

Acceptance 05-04-2017, Published 13-04-2017.

Corresponding Author:

Dr. Tatireddy Narasi Reddy,

H. No. 49/1-9,

Maddur Nagar, Kurnool-518002,

Andhra Pradesh.

E-mail: narasireddy06@yahoo.com

DOI: $10.14260 /$ jemds $/ 2017 / 519$

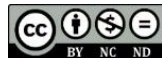

Patients of all age groups with involvement of at least one eye were included in the study. All the patients who were included in the study underwent visual acuity testing using logMAR (Logarithm of minimal angle of resolution) charts. Distance and near visual acuity, both presenting and best corrected after refraction, were measured for each eye separately using logMAR (Logarithm of minimum angle of resolution) charts.(6) External eye and anterior segment examination were done with slit-lamp biomicroscope, intraocular pressure measurement using Goldmann Applanation Tonometry. All participants had their pupils dilated and after dilatation the lens was examined with the slit-lamp and nuclear cataract was graded according to the Lens Opacities Classification System III(7) and cortical and posterior subcapsular cataracts were graded using the Wilmer classification.(8) Stereoscopic fundus examination, including assessment of the vitreous, retina, and optic disc, was done with the slit-lamp using 78 dioptre lens and with the indirect ophthalmoscope using 20 dioptre lens.

\section{RESULTS}

\begin{tabular}{|c|c|c|c|}
\hline Age & Males & Females & Total \\
\hline 0 -10 years & 2 & 0 & $2(10 \%)$ \\
\hline $10-20$ years & 1 & 0 & $1(5 \%)$ \\
\hline $20-30$ years & 4 & 2 & $6(30 \%)$ \\
\hline
\end{tabular}




\begin{tabular}{|c|c|c|c|}
\hline 30-40 years & 2 & 0 & $2(10 \%)$ \\
\hline $40-50$ years & 3 & 3 & $6(30 \%)$ \\
\hline >50 years & 1 & 2 & $3(15 \%)$ \\
\hline Total & $\mathbf{1 3}$ & $\mathbf{7}$ & $\mathbf{2 0}(\mathbf{1 0 0 \% )}$ \\
\hline \multicolumn{4}{|r|}{ Table 1. Occurrence of Corneal Blindness in Different Age } \\
and Gender Groups \\
\hline
\end{tabular}

\begin{tabular}{|c|c|c|c|c|}
\hline & RE & LE & BE & Total \\
\hline Males & 5 & 6 & 2 & $13(65 \%)$ \\
\hline Females & 3 & 4 & 0 & $7(35 \%)$ \\
\hline \multicolumn{4}{|c|}{ Table 2. Laterality of the Eye Involved } \\
\hline
\end{tabular}

\begin{tabular}{|c|c|}
\hline Causes of Corneal Blindness & Number \\
\hline Ocular trauma & $9(45 \%)$ \\
\hline Keratitis during childhood & $5(25 \%)$ \\
\hline Corneal scarring & $3(15 \%)$ \\
\hline Keratoconus & $1(5 \%)$ \\
\hline Microcornea & $2(10 \%)$ \\
\hline Total & $20(100 \%)$ \\
\hline Table 3. Causes of Corneal Blindness \\
\hline
\end{tabular}

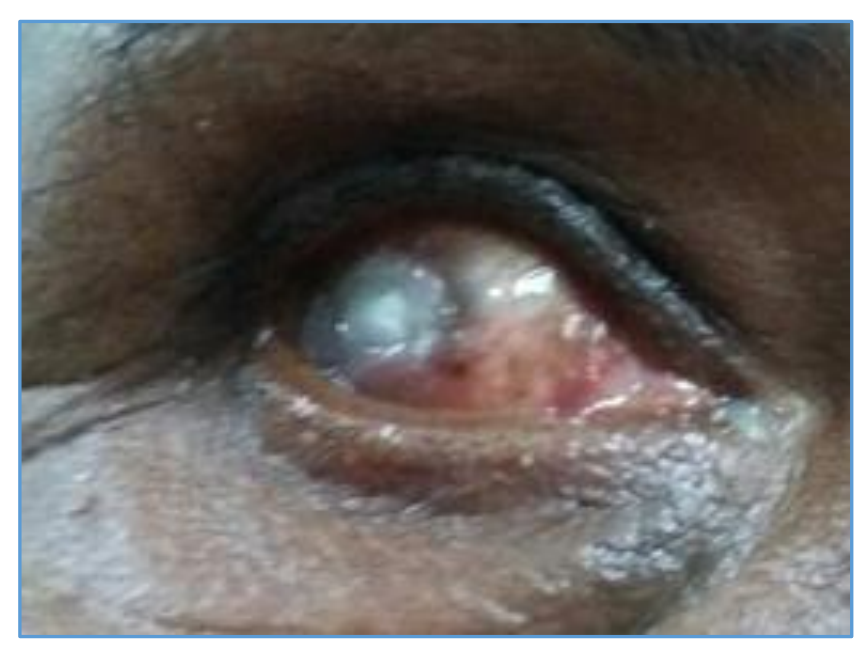

Figure 1. Central Corneal Opacity

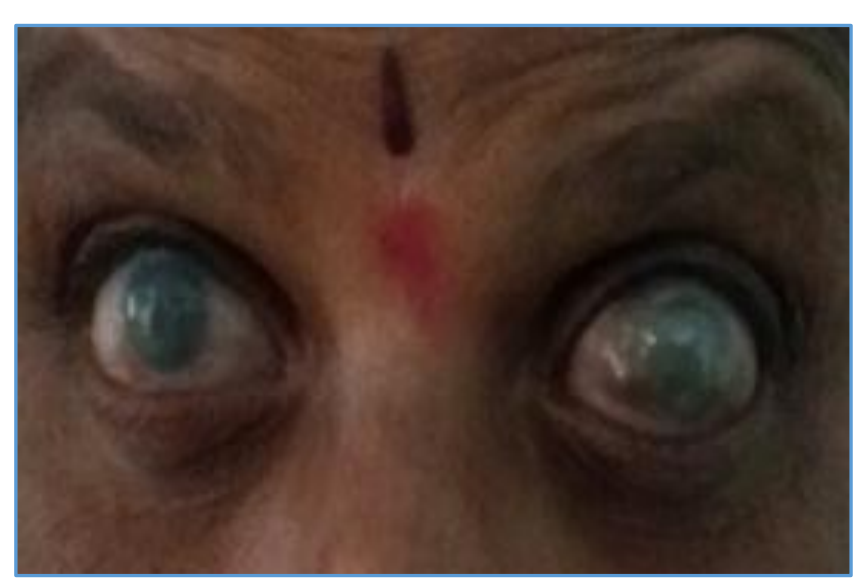

Figure 2. Total Corneal Opacity, Both Eyes

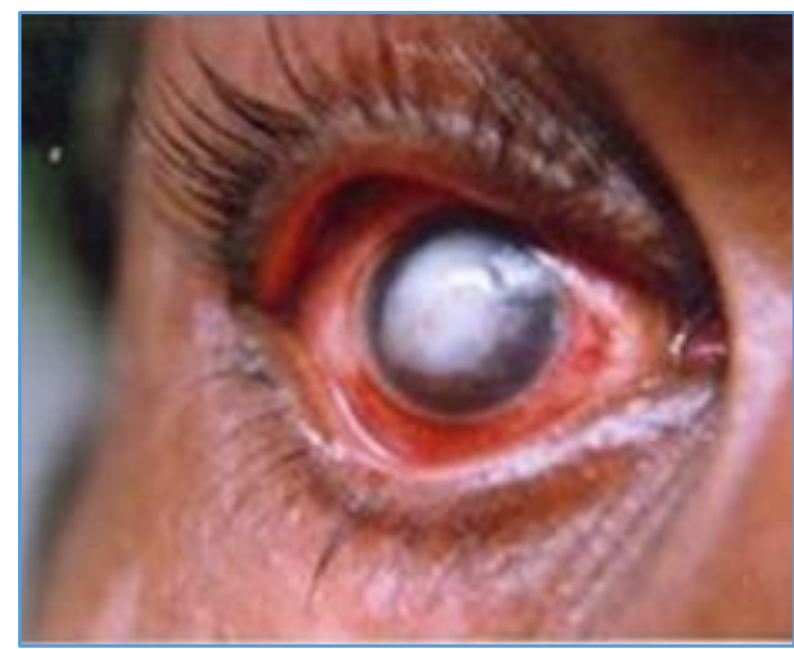

Figure 3. Leucomatous Corneal Opacity

\section{DISCUSSION}

Blindness is defined as presenting visual acuity $<6 / 60$ in the better eye with best corrected visual acuity $<3 / 60$ and/or less than 10 degrees visual field in better eye.

The external location of cornea predisposes it to a variety of sight threatening insults. Diseases affecting the cornea are a major cause of blindness worldwide.(9)

In India, ocular trauma, infectious keratitis, corneal ulceration and post-infectious keratitis corneo-iridic scars contribute significantly to the paediatric ocular morbidity whereas in adults, the major causes of corneal blindness include bacterial, fungal or viral keratitis, hereditary corneal dystrophy and eye injuries.(10)

In our study, males (65\%) were predominantly involved compared to females (35\%) which is likely related to their lifestyle or occupation.

In our study, ocular trauma (45\%) contributed to the major cause of corneal blindness. Trauma has been reported to be one of the most important causes of unilateral vision loss in developing countries.(11) Males have been reported to have a higher chance of suffering ocular trauma compared with females. In a study from South India, corneal injury was identified as a cause of infective keratitis in 70.88\% (2256 of 3183) patients.(12) Similarly, a hospital-based study from West Bengal reported that ocular trauma was the most common predisposing factor for development of microbial keratitis in 994 (82.9\%) patients. ${ }^{(13)}$

Keratitis during childhood (25\%) was the second major cause of corneal blindness in our study. Vitamin A deficiency precipitates in malnourished children who get debilitating fever, which can lead to blindness due to xerophthalmia.

Corneal scar (15\%) following keratitis during adulthood was the next common cause of corneal blindness in our study. A hospital based study from southern India has reported that corneal scarring was the most common indication for penetrating keratoplasty, half of which was due to keratitis.(14)

Other causes like keratoconus (5\%) and microcornea $(10 \%)$ also contributed to the causes of corneal blindness in our study. 
Keratoconus does not typically lead to complete blindness. But the disease can degrade vision to a level where one will experience difficulty in leading a normal life. Corneal hydrops (extensive scarring) can occur as the disease progresses. This can lead to legal blindness.

The corneal blindness can be reduced by conducting various health promotion programmes. Health promotion programmes to reduce corneal blindness need to target those who are identified to be at a higher risk of suffering from corneal blindness, based on the epidemiological data. For these programmes to have an impact, the government, nongovernmental organisations, eye health professionals including the ophthalmologists, and the community must be involved, and these programmes need to be integrated with the other relevant health and safety programmes. These health promotion programmes should focus on increasing awareness about the risk and consequences of corneal blindness, possible safety and prevention procedures to be followed to reduce the risk of corneal blindness, and the benefit of early detection and treatment if the need arises.

\section{CONCLUSION}

In our study, it was concluded that the proportion of corneal blindness was $13.3 \%$ among the patients who attended Regional Eye Hospital, Kurnool for blindness certificates indicating that corneal causes constitute one of the leading causes of blindness.

Males (65\%) are more affected than females (35\%) because of their occupational exposure.

Among the ocular causes, ocular trauma (45\%) constituted to be the main cause of corneal blindness in our study followed by keratitis during childhood (25\%), followed by corneal scarring due to keratitis during adulthood (15\%). Other causes for corneal blindness in our study include keratoconus (5\%) and microcornea (10\%).

\section{REFERENCES}

[1] Garg P, Krishna PV, Stratis AK, et al. The value of corneal transplantation in reducing blindness. Eye (Lond) 2005;19(10):1106-14.
[2] Causes of blindness and visual impairment. http://www.who.int/blindness/causes/en/. 2011

[3] National Programme for Control of Blindness. Report of National Programme for Control of Blindness, India and World Health Organization, 1986-89.

[4] Dandona R, Dandona L. Corneal blindness in a southern Indian population: Need for health promotion strategies. $\mathrm{Br} \quad \mathrm{J}$ Ophthalmol 2003;87(2):133-41.

[5] Whitcher JP, Srinivasan M, Upadhyay MP. Corneal blindness: a global perspective. Bull World Health Organ 2001;79(3):214-21.

[6] Ferris FL, Kassoff A, Bresnick GH, et al. New visual acuity charts for clinical research. Am J Ophthalmol 1982;94(1):91-6.

[7] Chylack LT, Wolfe JK, Singer DM, et al. The lens opacities classification system III. The Longitudinal Study of Cataract Study Group. Arch Ophthalmol 1993;111(6):831-6.

[8] Taylor HR, West SK. A simple system for the clinical grading of lens opacities. Lens Res 1988;5(1-2):17581.

[9] Thylefors B, Negrel AD, Pararajasegaram R, et al. Global data on blindness. Bull World Health Organ 1995;73(1):115-21.

[10] Gupta N, Tandon R, Gupta SK, et al. Burden of corneal blindness in India. Indian J Community Med 2013;38(4):198-206.

[11] Thylefors B. Epidemiological patterns of ocular trauma. Aust N Z JOphthalmol 1992;20(2):95-8.

[12] Bharathi MJ, Ramakrishnan R, Meenakshi R, et al. Microbial keratitis in South India: influence of risk factors, climate and geographical variation. Ophthalmic Epidemiol 2007;14(2):61-9.

[13] Basak SK, Basak S, Mohanta A, et al. Epidemiological and microbiological diagnosis of suppurative keratitis in gangetic West Bengal, eastern India. Indian J Ophthalmol 2005;53(1):17-22.

[14] Dandona L, Ragu K, Janarthanan M, et al. Indications for penetrating keratoplasty in India. Indian J Ophthalmol 1997;45(3):163-8. 